STUDIA I ARTYKUEY 



\section{RADA BISKUPIA - KOLEGIALNY ORGAN KONSULTACYJNY KURII DIECEZJALNEJ W SPRAWACH DUSZPASTERSKICH}

\section{Wstęp}

Włoski kanonista, bp Pierantonio Pavanello w artykule Il consiglio episcopale pisze, że $\mathrm{w}$ diecezjach, w których została utworzona rada biskupia, jawi się ona często jako tajemniczy organizm, któremu przypisuje się wielką moc, proporcjonalną do tajemniczości, która osłania jego działanie, i braku wiedzy o jego rzeczywistej funkcji. Tej aury tajemniczości nie pomaga rozwiać literatura kanonistyczna, która ogranicza się do potraktowania tego zagadnienia przeważnie w sposób ogólny, w ramach zagadnień o kurii diecezjalnej ${ }^{1}$.

Powstają zatem pytania. Jak powstawała norma kan. 473 § 4 Kodeksu Prawa Kanonicznego ${ }^{2}$ formalizująca instytucje rady biskupiej? Czy to gremium jest konieczne, czy nie? Kto wchodzi w skład rady biskupiej - czy tylko wikariusze generalni i wikariusze biskupi, czy też można dołączyć inne osoby, szczególnie te pełniące posługę w kurii diecezjalnej. Jaka jest relacja wspomnianego gremium do rady kapłańskiej i kurii diecezjalnej?

Próbą odpowiedzi na te pytania-problemy jest poniższy artykuł, w którym w oparciu o normy prawa powszechnego i wybrane ustalenia

* Dr hab., Wyższe Seminarium Duchowne w Radomiu; e-mail: ksjerzyad@wp.pl.

1 P. Pavanello, Il consiglio episcopale (can. 473 § 4). Commento a un canone, "Quaderni di Diritto Ecclesiale" 18(2005), nr 1, s. 70. Wszystkie tłumaczenia z języków obcych pochodzą od autora tego artykułu.

2 Codex Iuris Canonici auctoritate Ioannis Pauli PP. II promulgatus. Kodeks Prawa Kanonicznego, przekład polski zatwierdzony przez Konferencje Episkopatu, Poznań 1984 (dalej: KPK). 
prawa partykularnego ${ }^{3}$ ukaże się kodeksową instytucję kanoniczną, jaką jest rada biskupia - organ doradczy w kurii diecezjalnej w sprawach duszpasterskich.

\section{Geneza kan. 473 § 4 KPK}

Instytucja „rady biskupiej” jest nowa w życiu Kościoła partykularnego. Jej rozwój w prawie był równoczesny z powstaniem figury moderatora kurii diecezjalnej ${ }^{4}$. Pierwszy projekt rewizji KPK o kurii diecezjalnej zawierał normę o radzie biskupiej. Zamieszczono w nim następujący tekst:

Jeśli biskup diecezjalny uzna za stosowne dla właściwego zarządzania diecezją, może ustanowić radę biskupią. Rada ta, która faktycznie jest już obecna w kilku diecezjach, składa się z wikariusza generalnego, wikariuszy biskupich i niektórych innych osób, które zostaną wybrane przez biskupa ${ }^{5}$.

Przywołany tekst przyznawał biskupowi diecezjalnemu wolność w utworzeniu rady biskupiej, jeśli uznał on ją za potrzebną dla uporządkowanego rządzenia podległą mu diecezją. W tekście stwierdzono, że instytucja ta jest już rzeczywistością w wielu diecezjach. Według przytoczonej propozycji przyszłego kanonu, członkostwo w radzie biskupiej mogłoby obejmować wikariuszy generalnych i biskupich oraz pewne „inne osoby" wybrane przez biskupa. Nie podano żadnych kwalifikacji owych „niektórych innych osób” z wyjątkiem tego, że mają być wybrani przez biskupa. Jak wynika z tekstu, mogli to być duchowni lub świeccy.

3 Ze względu na szczupłość ram artykułu przedstawione zostaną tylko wybrane przepisy prawa partykularnego.

4 Z protokołów komisji kodyfikacyjnej wynika, że propozycja nowego organizmu, jakim jest rada biskupia, rodziła się z doświadczenia podobnych rad - różnie nazywanych (rada kurii, rada wikariuszy itp.) - już istniejących w wielu diecezjach. Więcej, istnienie takich rad stało się argumentem aby umieścić w Kodeksie ich szczegółową regulację, wbrew tym, którzy uważali to za niepotrzebne i woleliby pozostawić te unormowania prawu partykularnemu, zob. P. Pavanello, Il consiglio episcopale (can. 473 §)..., s. 71; Pontificia Commissio Codici Iuris Canonici Recognoscendo, Coetus studii «De sacra Hierarchia» (olim «De Clericis») (Sessio VI), "Communicationes" 24(1992), s. 47-48.

5 Pontificia Commissio Codici Iuris Canonici Recognoscendo, Opera Consultorum in parandis canonum schematibus, II. De Clericis-De Sacra Hierarchia, "Communicationes" 5(1973), s. 225-226. 
Schemat KPK z 1977 r. ${ }^{6}$ zachował istotę tej formuły z jedną zasadniczą zmianą - kan. 285 § 3 schematu zawierający normę o radzie biskupiej, brzmiał następująco:

Jeśli biskup uzna to za wskazane dla właściwego zarządzania diecezją, niech sobie ustanowi radę biskupią złożoną z wikariuszy generalnych i wikariuszy biskupich oraz innych duchownych przez niego wybranych ${ }^{7}$.

Podtrzymując fakultatywny charakter rady biskupiej, zaproponowany w poprzednim projekcie KPK, przywołany kan. $285 \S 3-\mathrm{w}$ porównaniu z poprzednią formułą - ograniczył członkostwo w niej, gdyż do rady biskupiej mogliby należeć „niektórzy inni duchowni” wybrani przez biskupa. Wspomniani "duchowni” mogliby być prezbiterami, a nawet diakonami, ale ich członkostwo w radzie nadal zależeć miało od wyboru biskupa.

Członkostwo w radzie biskupiej jeszcze bardziej ograniczono w Schema Codicis Iuris Canonici z 1980 r. ${ }^{8}$ W dniach 14-19 kwietnia 1980 r. zespół konsultorów przeanalizował kan. 285 i 286 schematu KPK z 1977 r. Odnośnie do znaczenia i członkostwa w radzie biskupiej podczas dyskusji pojawiły się dwa różne poglądy9. Niektórzy konsultorzy zakwestionowali potrzebę samej instytucji rady biskupiej. Uznali ustanowienie tego gremium za niewłaściwe, gdyż uważali, że może ono nadawać administracji diecezjalnej zbyt kolegialny charakter. Dlatego zaproponowali jej wyeliminowanie z KPK. To pozwoliłoby biskupowi opracować formy koordynacji działalności duszpasterskiej jego wikariuszy odpowiadającej sytuacji danego Kościoła partykularnego. Inni konsultorzy byli za utrzymaniem tej instytucji. Twierdzili, że istnienie i użyteczność rady biskupiej

6 Pontificia Commissio Codici Iuris Canonici Recognoscendo, Schema „De Populo Dei", Typis Polyglottis Vaticanis 1977 (dalej: schemat KPK z 1977 r.); tekst w j. polskim: Schemat "O Ludzie Bożym”, [w:] E. Sztafrowski (red.), Posoborowe Prawodawstwo Kościelne, t. 10, z. 2, Warszawa 1979, s. 125-388.

7 Kan. 285 § 3 schematu KPK z 1977 r.; zob A. Mendonca, The Structural Components of the Diocesan Curia, "Canonical Studies” 16 (2002), http:/ / www.canonlawsocietyindia.org [dostęp: 2.06.2017 r.]; A. Perez Diaz, Los vicarios generales y episcopales en el Derecho Canónico actual, Roma 1996, s. 27.

8 Schema Codicis Iuris Canonici, Libreria Editrice Vaticana 1980 (dalej: schemat KPK z 1980 r.); zob. P. Pavanello, Il consiglio episcopale (can. 473 § 4).., s. 71.

9 Odnośnie do szczegółów dyskusji, zob. Pontificia Commissio Codici Iuris Canonici Recognoscendo, Opera Consultorum in recognoscendis schematibus canonum. Coetus "De populo Dei», „Communicationes" 13(1981), s. 111-117, 122-123. 
w niektórych diecezjach wymagałyby dla niej określonej struktury kanonicznej ${ }^{10}$. W świetle tej różnicy poglądów osiągnięto kompromis, który pozwoliłby na zachowanie w przyszłym kodeksie rady biskupiej, lecz poddanej pewnym modyfikacjom - w celu uniknięcia nieporozumień - co do charakteru jej działań: czy decyzje rady byłyby kolegialne, czy jedynie konsultacyjne.

W ramach wspomnianego kompromisu najpierw usunięto wzmiankę o „innych duchownych” ze schematu KPK z 1977 r. i, w konsekwencji, członkostwo $\mathrm{w}$ radzie zostało zacieśnione tylko do wikariuszy biskupa. Z kolei usunięto z kanonu wszelkie wyraźne wzmianki o "zarządzaniu" rady, które zastąpiono deklaracją o jej celowości: „dla bardziej odpowiedniego promowania działalności pasterskiej”. Propozycja ta została zaakceptowana przez członków komisji, ponieważ oznaczała, że „rada biskupia ma być dopełnieniem, a nie alternatywą dla obecności biskupa diecezjalnego"11. Z tymi poprawkami kan. 285 § 4 schematu KPK z 1977 r. przeszedł jako kan. 393 § 4 do schematu KPK z 1980 r. ${ }^{12}$

Podczas sesji plenarnej Komisji Kodyfikacyjnej w październiku 1981 r. jeden z członków zasugerował, aby rada biskupia obejmowała inne osoby kierujące diecezjalnymi urzędami duszpasterskimi, w tym kapłanów, którzy nie są wikariuszami biskupa, osób konsekrowanych mających święcenia oraz członków stowarzyszeń życia apostolskiego, a nawet świeckich (moderatora kurii i innych, którzy wykonują funkcje administracyjne w diecezji w imieniu biskupa). Sekretarz Komisji odpowiedział, że sugerowana zmiana składu rady zmieniłaby sam charakter rady biskupiej, która stanowi „szczególną i ścisłą współpracę z biskupem diecezjalnym w tych sprawach, które dotyczą całego duszpasterskiego zarządzania diecezją"13.

10 Zob. A. Perez Diaz, Los vicarios generales y episcopales..., s. 29.

11 Pontificia Commissio Codici Iuris Canonici Recognoscendo, Opera Consultorum in recognoscendis schematibus canonum. Coetus «De populo Dei»..., s. 117; zob. P. Pavanello, Il consiglio episcopale (can. 473 § 4)..., s. 71-72.

12 Kan. 393 § 4 schematu KPK z 1980 r.: „Ubi id expedire iudicaverit, Episcopus, ad actionem pastoralem aptius fovendam, constituere potest consilium episcopale, constans scilicet Vicariis generalibus et Vicariis episcopalibus". Zob. A. Perez Diaz, Los vicarios generales y episcopales..., s. 29-30.

$13, \ldots[$ c... cuius est peculiaris et arcta cooperation cum Episcopo diocesano in is quae ad universum regimen pastorale diocesis pertinent", Pontificia Commissio Codici Iuris Canonici Recognoscendo, Opera consultorum in recognoscendis schematibus canonum. Coetus «De populo Dei», "Communicationes” 14(1982), s. 213; zob. P. Pavanello, Il consiglio episcopale (can. 473 § 4)..., s. 71; A. Perez Diaz, Los vicarios generales y episcopales..., s. 30. 
Przytoczone modyfikacje przepisów o radzie biskupiej w czasie prac redakcyjnych miały na celu doprecyzowanie samej natury i celu wspomnianego gremium: być skutecznym środkiem komunikacji i współpracy między biskupem a jego wikariuszami w odniesieniu do działalności duszpasterskiej. Z tymi zmianami norma o radzie biskupiej stała się § 4 kan. 473 Schema novissimum KPK z 1982 r. ${ }^{14}$ Poza kilkoma niewielkimi zmianami technicznymi, kanon ten pozostał niezmieniony w ogłoszonym tekście KPK jako kan. $473 \S 4^{15}$, który brzmi: „gdzie biskup uzna to za wskazane dla bardziej odpowiedniego spotęgowania działalności pasterskiej, może ustanowić radę biskupią, złożoną z wikariuszy generalnych i wikariuszy biskupich".

\section{Natura rady biskupiej i problem jej powoływania}

Tak zatem kan. 473 § 4 KPK ustanawia i reguluje nowe narzędzie koordynacyjne $\mathrm{w}$ diecezji, $\mathrm{w}$ tym przypadku nie indywidualne, lecz zbiorowe, kolegialne, jakim jest rada biskupia. Przywołany kanon jest jedynym miejscem w KPK, gdzie wspomina się nowy organizm, którego funkcja jest opisana w sposób bardzo ogólny: „dla bardziej odpowiedniego spotęgowania działalności pasterskiej”. Jest to w istocie podmiot, który jest częścią organizacji niektórych Kościołów partykularnych, nieobowiązkowy do ustanawiania we wszystkich diecezjach ${ }^{16}$. Funkcje koordynacyjne aktywności wikariuszy diecezjalnych można bowiem realizować bez formalnego ustanawiania rady biskupiej ${ }^{17}$. Historia redakcji przepisów o radzie biskupiej ukazuje, że gremium to jest kształtowane przez wikariusza

14 Codex Iuris Canonici. Schema novissimum iuxta placita Patrum Commissionis emendatum atque Summo Pontifici praesentatum, Typis Polyglottis Vaticanis 1982 (dalej: Schema novissimum KPK z 1982 r.).

15 Zob. A. Mendonca, The Structural Components...

16 Juan Ignacio Arrieta zauważa, że czynnikiem, który określa takie organy jak rada biskupia czy rada do spraw ekonomicznych, jest ich udział w zwyczajnym sprawowaniu władzy biskupiej, w zakresie, w jakim są one częścią struktury administracyjnej diecezji, a ich członkowie wykonują swoje zadania kierując się określonymi przepisami prawnymi, na podstawie których działają $\mathrm{w}$ ramach kompetencji zakreślonych dla każdego $\mathrm{z}$ tych organów przez prawo, zob. J.I. Arrieta, Órganos de partecipación y corresponsabilidad en la Iglesia diocesana, „Ius canonicum” 34(1994), nr 68, s. 555.

17 Zob. A. Viana, Comentario al can. 473, [w:] A. Marzoa, J. Miras, R. Rodríguez-Ocaña (red.), Comentario exegético al Código de Derecho Canónico, t. 2, Pamplona 1996³, s. 1049. 
generalnego i wikariuszy biskupich, czyli tych kapłanów, którzy sprawują w formie zastępczej własną władzę wykonawczą biskupa diecezjalnego. Cel rady nie ogranicza się do koordynowania działalności kurii (bo o tym traktuje kan. 473 § 2 KPK, ukazując moderatora kurii, jako jej koordynatora), ale odnosi się do całej aktywności duszpasterskiej diecezji. Potwierdzeniem tego jest fakt, że od pierwszej redakcji kanonu o radzie biskupiej, w którym mówiło się o jej udziale w zarządzaniu diecezją, przemierzono długą drogę redakcyjną, aby w aktualnym kanonie odnieść się do rzeczywistości szerszej i bardziej ogólnej, jaką jest udział rady w działalności duszpasterskiej ${ }^{18}$.

Według KPK z 1983 r. (kan. 473 § 4) biskup będzie mógł ustanowić radę biskupią, gdy uzna to za wskazane dla bardziej odpowiedniego spotęgowania działalności pasterskiej. Podobnie mówi Direttorio per il ministero pastorale dei vescovi "Apostolorum successores":

Koordynowanie działalności duszpasterskiej w diecezji należy oczywiście do biskupa diecezjalnego, któremu bezpośrednio podlegają wikariusze generalni i wikariusze biskupi. Jeśli biskup uzna to za wskazane, może powołać radę biskupią, złożoną z wikariuszy, w celu koordynowania całego diecezjalnego duszpasterstwa ${ }^{19}$.

Również Adhortacja apostolska „Pastores gregis” zawiera wzmiankę o możliwości powołania rady biskupiej:

Doświadczenie komunii kościelnej będzie dla biskupa szkołą stylu pasterskiego coraz bardziej otwartego na współpracę ze wszystkimi. Istnieje wzajemne oddziaływanie pomiędzy decyzjami, które biskup powinien podejmować jako osobiście odpowiedzialny za dobro powierzonego mu Kościoła, oraz wkładem, jaki wierni mogą wnosić poprzez organy doradcze, jak synod diecezjalny, rada kapłańska, rada biskupia, rada duszpasterska ${ }^{20}$.

18 Zob. P. Pavanello, Il consiglio episcopale (can. 473 § 4)..., s. 71-72.

19 Congregaticio pro Episcopis, Direttorio per il ministero pastorale dei vescovi "Apostolorum successores" (22 febbraio 2004), 178, Città del Vaticano 2004; tekst w j. polskim: Kongregacja do spraw Biskupów, Dyrektorium o pasterskiej postudze biskupów „Apostolorum Successores", Kielce 2005 (dalej: AS).

20 Ioannes Paulus PP. II, Adhortatio apostolica post-synodalis de Episcopo ministro evangelii Iesu Christi pro mundi spe "Pastores gregis" (16 octobris 2003), 44, "Acta Apostolicae Sedis” 96(2004), s. 825-924 (dalej: AAS); tekst w j. polskim: Jan Paweł II, Posynodalna adhortacja apostolska "Pastores gregis" Ojca Świętego Jana Pawła II. O biskupie studze Ewangelii Jezusa Chrystusa dla nadziei świata, „L'Osservatore Romano” [wyd. pol.] 25(2004), nr 1 (259), s. 4-48. 
Jednak przywołani prawodawcy nie podają dalszych kryteriów oceny, która będzie skłaniać do wykorzystania możliwości powołania rady. Z uwagi jednak na to, że KPK w sposób zdecydowany, nie budzący wątpliwości, przewiduje skład rady, to rada biskupia nie będzie mogła być tworzona w tych diecezjach, w których biskup nie uzna za konieczne, aby mianować wikariuszy biskupich ${ }^{21}$.

Rada biskupia może okazać się pożyteczna szczególnie w diecezjach z wieloma wikariuszami administracyjnymi (wikariuszami biskupa), a także do bardziej skutecznego wdrożenia postanowień kan. $407 \mathrm{KPK}$, traktującego o wzajemnych konsultacjach między biskupem diecezjalnym, koadiutorem i biskupami pomocniczymi. Trzeba dodać, że omawiana rada nie jest organem przedstawicielskim urzędów diecezjalnych, nawet tych administracyjnych należących do kurii, ponieważ KPK określa, że składa się ona tylko z wikariuszy generalnych i biskupich ${ }^{22}$.

Należy wreszcie skonstatować, że celem rady biskupiej nie jest kolegialne wykonywanie władzy administracyjnej, lecz ujednolicenie kryteriów pracy, przekazywanie i otrzymywanie informacji lub wskazówek odnośnie do wykonywanych zadań lub wzajemne, osobiste wspieranie się. Chodzi, zatem o organizm, który służyłby wewnętrznej koordynacji działalności urzędów wikariuszy biskupa ${ }^{23}$.

Prawo partykularne niejednokrotnie wypowiada się na temat możliwości ustanowienia rady biskupiej, sposobów jej funkcjonowania i zadań. Estatuto de la Curia Diocesana diecezji Palencia przytacza dosłownie przepis kan. 473 § 4: "gdzie biskup uzna to za wskazane dla bardziej odpowiedniego spotęgowania działalności pasterskiej, może ustanowić radę biskupią, złożoną z wikariuszy generalnych i wikariuszy biskupich" ${ }^{24}$. Estatutos de la Curia Diocesana de Asidonia-Jerez diócesis de Asidonia Jerez stwierdzają, że rada biskupia jest stałym organem kolegialnym troszczącym się o koordynację działalności administracyjnej i duszpasterskiej wikariuszy generalnych i biskupich, o odpowiedniej spójności i jedności kryteriów w odniesieniu do ważniejszych spraw. Przyczynia się ona do unikania czynności spóźnionych, sprzecznych i nieskutecznych oraz

21 Zob. P. Pavanello, Il consiglio episcopale (can. 473 § 4)..., s. 72.

22 Zob. A. Viana, Comentario al can. 473, s. 1049.

23 Zob. tamże, s. 1050; R. Serres López de Guereñu, La figura del vicario para la vida consagrada: aspectos canónicos, „Revista Espańola de Derecho Canónico” 62(2005), nr 159, s. 640.

${ }^{24}$ Obispado de Palencia, Estatuto de la Curia Diocesana (1 septiembre de 2012), art. 17, www.diocesispalencia.org [dostęp: 18.05.2017 r.]. 
tego wszystkiego, co szkodzi zarządzaniu diecezją ${ }^{25}$. Wspomniany staut podkreśla z naciskiem, że rada biskupia, jako organ wyłącznie koordynacyjny, jest pozbawiona zarówno władzy ustawodawczej, jak i władzy administracyjnej $\mathrm{w}$ sensie ścisłym ${ }^{26}$. Rada jest miejscem, $\mathrm{w}$ ramach którego wikariusze mogą skonsultować z biskupem istotniejsze sprawy, rozwiązywać i informować biskupa o ważnych sprawach już rozstrzygniętych, korzystając przy tym $w$ tych konsultacjach $\mathrm{z}$ informacji i wsparcia ze strony innych urzędów, które należą do rady. Rada przygotowuje akty zarządzania, które będą pomocą dla kompetentnej władzy w realizowaniu jej uprawnień. Sprawy nierostrzygnięte podczas konsultacji i wymiany poglądów na forum rady, zawsze mają być pozostawione ostatecznej decyzji biskupa. Biskup będzie mógł zawsze wyłączyć z dyskusji pewne tematy albo propozycje i zastrzec sobie osobiste studiowanie i rozpatrywanie określonych zagadnień. W celu ujednolicenia kryteriów i odpowiedniego przygotowania sesji rady biskupiej, członkowie rady zwołani przez wikariusza generalnego, będą mogli zbierać się regularnie ${ }^{27}$.

Regulacje zawarte w Statuto della Curia Diocesana della diocesi di Albenga-Imperia podkreślają, że „,wikariusz biskupi dzieli z biskupem i z innymi wikariuszami, skupionymi w radzie biskupiej, odpowiedzialność w kwestii zarządzania pasterskiego wobec całej diecezji" ${ }^{28}$, natomiast Estatuto de la Curia Diocesana de la Archidiócesis de Madrid przypomina, że rada biskupia jest współpracownikiem „arcybiskupa w zarządzie diecezją, jako organ koordynacji i konsultacji" 29 .

Estatuto de la Curia Diocesana diecezji Pamplona i Tudela, postanawia, że rada biskupia ma wspomagać arcybiskupa we wszystkich sprawach związanych z zarządzaniem, kiedy potrzebuje on przeprowadzenia rozmów, konsultacji i podjęcia decyzji przy jej pomocy i współpracy. Rada ta ma odpowiednio koordynować działalność duszpasterstwa diecezjalnego,

25 Zob. Estatutos de la Curia Diocesana de Asidonia-Jerez diócesis de Asidonia-Jerez, „Boletín Oficial del Obispado de Asidonia-Jerez", epoca 2, separata nr 14, art. 13 § 1, https:// www.diocesisdejerez.org/index.../separatas-2001-2008 [dostęp: 1.05.2017 r.].

26 Tamże, art. $13 \S 5$.

27 Zob. tamże, art. 14 § 2-4.

28 Statuto della Curia Diocesana della diocesi di Albenga-Imperia, art. 17, http://repertoriogiuridico.chiesacattolica.it/statuto-della-curia-della-diocesi-di-albenga-imperia [dostęp: 3.06.2017 r.].

29 Estatuto de la Curia Diocesana de la Archidiócesis de Madrid (1 marzo 1999), art. 4, http:/ / www.lavozdelcardenal.archimadrid.com [dostęp: 26.05.2017 r.]. 
szczególnie aktywność prawną i duszpasterską wikariusza generalnego i wikariuszy biskupich, ustalać wspólne kryteria i promować jednolitość zwyczajnego zarządzania diecezją, w drodze dialogu i wzajemnego informowania, przygotowywać akty zarządzania, które wikariusze winni później wdrażać, i wydawać polecenia w razie potrzeby, badać i przygotować nominacje kościelne, biorąc pod uwagę potrzeby i ich stosowność pastoralną, określać kompozycję i dyrektywy dla agend duszpasterskich kurii oraz poruszać zagadnienia o szczególnej doniosłości dla życia diecezji, zarówno w dziedzinie duszpasterstwa, jak i w administracji i ekonomii, a także rozpatrywać zagadnienia odnoszące się do duchowieństwa, zarówno jeśli chodzi o osoby, jak i o działalność duszpasterską, o ich prawa, obowiązki, dyscyplinę, życie duchowe czy formację $e^{30}$.

Estatuto de la Curia Diocesana de Ávila przypomina, że rada biskupia umożliwia, koordynuje i kieruje akcją duszpasterską, według kryteriów działania ustalonych przez biskupa. Wikariusze biskupi - członkowie rady - mają gromadzić i porządkować odpowiednie informacje odnoszące sie do potrzeb duszpasterskich swoich sektorów i przekazywać je biskupowi, aby je przedłożył radzie biskupiej dla odpowiedniego rozważenia i rozwiązania ich przez biskupa ${ }^{31}$. Zgodnie ze Statuto della Curia Diocesana della diocesi di Albenga-Imperia dyrektorzy urzędów w kurii i wszyscy, który wypełniają funkcje urzędowe w kurii diecezjalnej winni służyć współpracą i sugestiami wikariuszowi generalnemu i radzie biskupiej ${ }^{32}$. Regulamin Kurii Diecezjalnej w Tarnowie przypomina, że „w sprawach związanych z zarządzaniem Diecezją pomocą służy Biskupowi, w zakresie przez niego określonym, Rada Biskupia (zob. kan. 473 § 4 KPK)"33.

Powstaje jednak pytanie o władzę rady biskupiej. Trzeba jasno stwierdzić, że consilium episcopale nie posiada swojej własnej władzy. Jedyną władzą w niej wykonywaną jest władza biskupa diecezjalnego. Nie znaczy to, że władza zwyczajna wikariuszy, kiedy biorą udział w radzie biskupiej jest zawieszana, ale po prostu to, że postanowienia rady muszą

30 Zob. Diócesis de Pamplona y Tudela, Estatuto de la Curia Diocesana (1 noviembre 2003), art. 7, nr 7.2, http:/ / www. iglesianavarra.org [dostęp: 26.05.2017 r.].

31 Zob. Estatuto de la Curia Diocesana de Ávila (3 abril 2002), Ávila 2002, art. 12, nr 1-2.

32 Zob. Statuto della Curia Diocesana della diocesi di Albenga-Imperia, art. 21.

33 Regulamin Kurii Diecezjalnej w Tarnowie (31 grudnia 2010), rozdz. 1, nr 5, "Currenda” 161(2011), nr 1, s. 63. Autor przestudiował wiele statutów i regulaminów kurii diecezjalnych w Polsce i doszedł do wnioskiu, że rada biskupia w polskich kuriach diecezjalnych występuje niezwykle rzadko. 
jednak być przyznane do wykonywania władzy własnej biskupa diecezjalnego nawet, gdy są podejmowane po konsultacji i wspólnej refleksji $\mathrm{z}$ jego wikariuszami. Jest zatem niesłuszne przypisywanie radzie biskupiej kompetencji do podejmowania decyzji: rada ta $\mathrm{w}$ rzeczywistości nie jest kolegialnym organem zarządzającym. W przeciwieństwie do tego, co dzieje się w Kościele powszechnym, gdzie obok władzy osobistej papieża sytuuje się władza kolegialna Kolegium Biskupów, w Kościele partykularnym istnieje tylko władza osobista biskupa. Z drugiej strony nie można mówić wyłącznie o funkcji czysto doradczej rady biskupiej: w przeciwieństwie do członków rady kapłańskiej, wikariusze biskupa nie mają jedynie zadania doradzania biskupowi, ale oni także realizują jego decyzje, nie jako zwyczajni wykonawcy, ale jak tytulariusze prawdziwej władzy ${ }^{34}$. Funkcja rady biskupiej oraz rodzaj władzy tam sprawowanej konsekwentnie mogą być rozumiane jedynie uwzględniając zastępczy charakter władzy jej członków. Zarówno tradycyjna postać wikariusza generalnego, jak i ta nowa - wikariuszy biskupich, odwołuje się z jednej strony do pewnej decentralizacji władzy biskupiej, a z drugiej do instrumentalnego charakteru funkcji wikariuszy względem biskupa diecezjalnego. Innymi słowy, biorąc pod uwagę złożoność funkcjonowania władzy biskupiej, konieczne jest, aby biskup mógł działać za pośrednictwem innych podmiotów ściśle z nim związanych, które nie tylko będą go reprezentować, ale wykonywać jego władzę na terytorium i w różnych sektorach życia diecezjalnego. Dlatego wydaje się, że rada biskupia, w przeciwieństwie na przykład do rady kapłańskiej, która pełni wyłącznie rolę doradczą, jest organem wykonawczym. Może być ona porównana do grupy roboczej, gdzie wikariusze odnoszą się do działań biskupa i jego współpracowników, gromadzą informacje o problemach i sytuacjach, studiują i naświetlają rozwiązania, przydzielają konkretne zadania i weryfikują ich realizację. Podobnie jak wikariusze, także i rada biskupia jest wyłącznie narzędziem będącym do dyspozycji biskupa diecezjalnego, aby mógł w sposób skuteczniejszy wykonywać swoją władzę administracyjną, co nie oznacza jednak rezygnacji z osobistej odpowiedzialności biskupa ${ }^{35}$.

34 Zob. A. Perez Diaz, Los vicarios generales y episcopales..., s. 72; P. Pavanello, Il consiglio episcopale (can. 473 § 4)..., s. 74; L. Chiappetta, Il Codice di Diritto Canonico. Commento giuridico-pastorale, Roma 1996, s. 598.

35 Zob. P. Pavanello, Il consiglio episcopale (can. $473 \S 4$ )..., s. 74-75; A. Viana, Comentario al can. 473, s. 1051. 
Słusznie zauważa A. Mendonca, że biskup nie powinien uważać swojej rady jako dekoracji służącej jedynie do przyozdobienia imponującej organizacji jego diecezji, lecz powinien traktować z szacunkiem i powagą decyzje i propozycje uczynione przez członków rady. Chociaż KPK nadal opisuje biskupstwo w sposób „monarchiczny”, biskup musi być otwarty na ducha kolegialnego w kierowaniu jego diecezją w szukaniu odpowiednich rozwiązań palących problemów, które dotyczą duszpasterskiego dobra jego ludu ${ }^{36}$.

\section{Kompozycja rady biskupiej}

Kanon 473 § 4 KPK mówiąc o radzie biskupiej wskazuje niedwuznacznie, że jest ona złożona z wikariuszy generalnych i wikariuszy biskupich. Dyrektorium o pasterskiej postudze biskupów "Apostolorum successores" stwierdza identycznie, że „jeśli biskup uzna to za wskazane, może powołać radę biskupią, złożoną z wikariuszy, w celu koordynowania całego diecezjalnego duszpasterstwa" ${ }^{37}$. Tak zatem członkami omawianego gremium są wyłącznie wikariusze biskupa.

Jak wcześniej ukazano, aż do schematu KPK z 1980 r. projekty kanonów o radzie biskupiej rzeczywiście przewidywały, że razem z wikariuszami generalnym i wikariuszami biskupimi, mogłyby być członkami rady także inne podmioty (w pierwszej redakcji z 1973 r. mówiło się ogólnikowo o innych osobach, ale potem zacieśniono członkostwo tylko do duchownych). Ukazana powyżej debata o kompozycji rady biskupiej jest interesująca, ponieważ ukazuje się w niej sama natura i funkcje rady. Decyzja konsultorów, aby ograniczyć skład rady tylko do wikariuszy generalnych i biskupich ma zatem kluczowe znaczenie także dla określenia jej celu. W tym kontekście znaczące jest, że podczas sesji plenarnej w 1980 r. odrzucono propozycję przewidującą udział $\mathrm{w}$ radzie biskupiej także innych wiernych (duchowni, osoby konsekrowane mające święcenia oraz członkowie stowarzyszeń życia apostolskiego i świeccy), którzy pełnią określone obowiązki w administracji diecezjalnej. Domniemanym powodem takiej decyzji było

36 Zob. A. Mendonca, The Structural Components...

37 Kongregacja do spraw Biskupów, Dyrektorium o pasterskiej postudze biskupów "Apostolorum successores", $\mathrm{nr} 178$. 
przeświadczenie konsultorów, że w przypadku dopuszczenia do udziału w radzie innych podmiotów niż wikariusze biskupa, zostałaby zmieniona sama natura rady biskupiej: „cuius est peculiaris et arcta cooperatio cum Episcopo dioecesano in iis quae ad universum regimen pastorale dioecesis pertinent" ${ }^{\prime 38}$. Należy więc skonstatować, że historia redakcji wyraźnie pokazuje, że rada biskupia jest konstytuowana przez wikariusza generalnego i wikariuszy biskupich, czyli tych kapłanów, którzy wykonują w formie zastępczej własną władzę wykonawczą biskupa diecezjalnego.

Pierantonio Pavanello zauważa, że pomimo wspomnianej negatywnej odpowiedzi danej w czasie sesji plenarnej w 1980 r. odnośnie do wniosku przewidującego włączenie do rady biskupiej oprócz wikariusza generalnego i wikariuszy biskupich innych podmiotów, w doktrynie i w praktyce trwa zamieszanie w tej kwestii ${ }^{39}$.

Wśród autorów przeważa opinia, że skład rady biskupiej przewidziany w kan. $473 \S 4$ KPK jest taksatywny (wyczerpujący), ale niektóry kanoniści dopuszczają także możliwość dokooptowania do składu rady innych podmiotów, z racji urzędu, który pełnią w diecezji - w szczególności: moderatora kurii (gdyby jego urząd nie był powierzony wikariuszowi generalnemu albo biskupiemu), kanclerza i wikariusza sądowego.

Do pierwszej grupy autorów należą F. Daneels ${ }^{40}$, G. Marchetti ${ }^{41}$, A. Perez Diaz ${ }^{42}$, A. Perlasca ${ }^{43}$, L. Chiappeta ${ }^{44}$, P. Pavanello ${ }^{45}$ czy G. Giuliani ${ }^{46}$. Do

38 Pontificia Commissio Codici Iuris Canonici Recognoscendo, Relatio complectens synthesim animadversionum ab Em.mis atque Exc.mis patribus Commissionis ad novissimum schema Codicis Iuris Canonici exhibitarum, cum responsionibus a secretaria et consultoribus datis, Città del Vaticano 1981, s. 112; zob. P. Pavanello, Il consiglio episcopale (can. 473 § 4)..., s. 71.

39 Zob. P. Pavanello, Il consiglio episcopale (can. $473 \S 4$ )..., s. 72.

40 Autor ten twierdzi, że nazwa „rada biskupia” wywodzi się z faktu, że uczestniczą w niej tylko wikariusze generalni i biskupi (nie wikariusz sądowy), a jej specyficzną funkcją jest urzeczywistnianie działalności duszpasterskiej biskupa i jego wikariuszy. Tak, że jeśli organ ten w rzeczywistości składa się także z innych podmiotów, to konsekwentnie nie powinien być nazywany radą biskupią, zob. F. Daneels, De dioecesanis corresponsabilitatis organis, „Periodica de Re Morali Canonica Liturgica” 74(1985), s. 309-310; A. Perlasca, I vicari generali ed episcopali, "Quaderni di Diritto Ecclesiale” 18(2005), nr 1, s. 46.

${ }^{41}$ G. Marchetti, La Curia come organo di partecipazione alla cura pastorale del vescovo diocesano, Roma 2000, s. 414.

42 A. Perez Diaz, Los vicarios generales y episcopales..., s. 30.

43 A. Perlasca, I vicari generali ed episcopali, s. 46.

44 Autor ten zauważa, że Komisja kodyfikacyjna wyraźnie oświadczyła, że włączenie do rady biskupiej kapłanów nie będących wikariuszami biskupa zmieniłoby naturę 
drugiej grupy kanonistów, którzy dopuszczają rozszerzenie składu rady biskupiej w szczególności o moderatora kurii (gdyby jego urząd nie był powierzony wikariuszowi generalnemu albo biskupiemu), kanclerzowi i wikariuszowi sądowemu należą: M. Morgante ${ }^{47}$, A. Viana ${ }^{48}$ i J. Krukowski ${ }^{49}$.

Historia redakcji kan. 473 § 4 KPK, który mówiąc o radzie biskupiej stwierdza niedwuznacznie, że jest ona złożona z wikariuszy generalnych i wikariuszy biskupich, a także przypomnienie Dyrektorium o pasterskiej postudze biskupów "Apostolorum successores”, gdzie mówi się, że „jeśli biskup uzna to za wskazane, może powołać radę biskupią, złożoną z wikariuszy,

tej rady, w której mają udział tylko ci, którzy mają uczestnictwo w biskupiej władzy rządzenia. Dlatego argumentuje, że moderator kurii, który nie jest jednocześnie wikariuszem biskupa i nawet wikariusz sądowy, są wykluczeni z rady biskupiej, ponieważ nie są oni wspomniani w kanonie, zob. L. Chiappetta, Il Codice di Diritto Canonico..., s. 598.

45 Autor stwierdza, że rada biskupia składa się tylko z wikariuszy biskupa, lecz jednocześnie jest zdania, że, gdy zaistnieje potrzeba, aby skorzystać z konkretnych kompetencji osób pracujących w różnych sektorach duszpasterskich, to będzie można ją zaspokoić zapraszając od czasu do czasu do prac rady biskupiej ekspertów od poszczególnych zagadnień, nad którymi się debatuje, zob. P. Pavanello, Il consiglio episcopale (can. 473 § 4)..., s. 73-74.

46 Giovanni Giuliani przypomina, że komponenty rady biskupiej nie mogą być inne niż te wskazane w kanonie: wikariusze generalni i wikariusze biskupi, zob tenże, I canoni generali sulla Curia diocesana, „Apollinaris” 61(1988), nr 1/2, s. 109-153.

47 Marcello Morgante utrzymuje, że wikariusz sądowy winien być członkiem rady biskupiej lub przynajmniej uczestniczyć w niej w sprawach związanych z jego urzędem. Idąc dalej sugeruje, że byłoby to odpowiednie, aby biskup zezwolił na udział moderatora kurii albo sekretarza generalnego, chociaż ściśle nie byliby oni członkami rady, w dyskusjach nad sprawami należącymi do ich zwyczajnej kompetencji, zob. M. Morgante, La Chiesa particolare nel Codice di Diritto Canonico: commento giuridico-pastorale, Milano 1987, s. 598, 215.

48 Autor lojalnie przypomina, że studiując prace przygotowawcze do sformułowania kan. 473 § 4 KPK wywiódł, iż w skład rady biskupiej wchodzą tylko wikariusze biskupa. Biorąc jednak pod uwagę, że chodzi o organ wyraźnie powiązany z kurią diecezjalną, który musi być regulowany przez prawo partykularne, dopuszcza jako członków rady biskupiej także moderatora kurii (także kiedy byłby on odrębny od wikariusza generalnego) i kanclerza (byłby członkiem na mocy natury czynności opisanych w kan. 474 i 482 § 1) oraz innych członków mianowanych przez biskupa diecezjalnego, zob. A. Viana Comentario al can. 473, s. 1049.

49 Autor pisze, że „powołanie [...] rady biskupiej ustawodawca pozostawia [...] swobodnemu uznaniu biskupa diecezjalnego. Jeśli uzna on za stosowne, może w jej skład powołać także inne osoby spełniające funkcje kierownicze różnych agend kurialnych, a zwłaszcza kierownika wydziału duszpasterskiego, jeśli nie jest on wikariuszem generalnym lub wikariuszem biskupim”, J. Krukowski, Komentarz do kan. 473, [w:] J. Krukowski (red.), Komentarz do Kodeksu Prawa Kanonicznego, t. 2, ks. 2, cz. 1. Lud Boży, Poznań 2005, s. 350. 
w celu koordynowania całego diecezjalnego duszpasterstwa"50, każe przyznać rację pierwszej grupie autorów. Tak zatem, jeśli rada biskupia ma być zgodna z jej naturą kodeksową i organ ten może się adekwatnie nazywać taką radą, to jej członkami są wyłącznie wikariusze biskupi.

Estatuto de la curia diocesana Diócesis de Albacete stwierdzają, że „wikariusze biskupi, z wikariuszem generalnym, tworzą radę biskupią, której przewodniczy biskup diecezjalny" ${ }^{51}$, natomiast Statuto della Curia Diocesana della diocesi di Albenga-Imperia zaznacza, że „wikariusz biskupi dzieli wraz z biskupem i innymi wikariuszami, skupionymi w radzie biskupiej, odpowiedzialność za zarządzanie duszpasterstwem w całej diecezji" ${ }^{52}$.

Statuto della Curia archidiecezji Neapolu stwierdza, że „aby popierać jednolitość akcji duszpasterskiej Kościoła w Neapolu i dobrą koordynację zarządzania Archidiecezją, według kan. $473 \S 4$ zostaje ukonstytuowana rada biskupia, organ kolegialny pod przewodnictwem arcybiskupa i tworzony przez wikariuszy generalnych i wikariuszy biskupich" 53 .

Niestety również prawodawcy partykularni wprowadzają zamieszanie $\mathrm{w}$ prawdziwą naturę rady biskupiej, gdy w swoich przepisach przewidują w jej kompozycji inne podmioty poza wikariuszami biskupa. Estatuto de la Curia Diocesana diecezji Palencia zawiera zapis: „aby lepiej promować akcję duszpasterską, może biskup utworzyć, jeśli uważa to za użyteczne, radę biskupią, ukształtowaną przez wikariusza generalnego i wikariuszy biskupich" ${ }^{24}$. Jednakże po przytoczeniu teksu kodeksowego prawodawca (co jest niezrozumiałe) postanawia: „rada biskupia diecezji Palencia będzie kształtowana przez biskupa, wikariusza generalnego, prowikariusza generalnego, wikariusza sądowego i wikariusza do spraw duszpasterstwa" 55 .

Z kolei Estatuto de la Curia Diocesana diecezji Pamplona i Tudela rozstrzyga, że „rada biskupia jest kształtowana przez wikariusza generalnego, wikariuszy biskupich do stref duszpasterskich i kanclerza-sekretarza

${ }^{50}$ Kongregacja do spraw Biskupów, Dyrektorium o pasterskiej postudze biskupów "Apostolorum successores", $\mathrm{nr} 178$.

51 Estatuto de la curia diocesana Diócesis de Albacete (8 diciembre 2003), art. 20 §1, http:/ / www.diocesisalbacete.org/documentos/transparencia [dostęp: 26.05.2017 r.].

52 Statuto della Curia Diocesana della diocesi di Albenga-Imperia, art. 17.

53 Arcidiocesi di Napoli, Statuto della Curia (14 settembre 2015), art. 22 § 1, http:// www.chiesadinapoli.it [dostęp: 3.06.2017 r.].

54 Obispado de Palencia, Estatuto de la Curia Diocesana, art. 17.

55 Tamże, art. 18. 
kurii" ${ }^{56}$. Następnie Estatuto de la Curia Diocesana de Astorga zawiera deklarację prawną, zgodnie z którą rada biskupia jest stałym organem kolegialnym o charakterze doradczym, który troszczy się o działalność prawną i duszpasterską wikariuszy generalnych i biskupich ${ }^{57}$. Jednakże dalej prawodawca stwierdza, że radzie przewodniczy biskup, do której należą wikariusz generalny oraz moderator kurii i inni wikariusze biskupi. Kanclerz-sekretarz generalny kurii jest sekretarzem rady biskupiej i sporządza protokół z kwestii poruszanych na zebraniach. Kiedy charakter problemów, nad którymi należy debatować tego wymaga, będą uczestniczyć w naradach rady biskupiej, jako goście, tytulariusze różnych urzędów kurii albo odpowiedzialni za inne instytucje diecezjalne ${ }^{58}$.

Estatutos de la Curia Diocesana de Asidonia-Jerez zawierają następującą dyspozycję: „rada biskupia jest stałym, koordynacyjnym organem kolegialnym, który troszczy się o właściwą działalność administracyjną i duszpasterską wikariusza generalnego i biskupich" - jednak zaraz dodaje się, że członkami tej rady pod prezydencją biskupa są: wikariusz generalny, moderator kurii, wikariusze do spraw duszpasterstwa i dziedziny ekonomii oraz sekretarz generalny-kanclerz. Sekretarz generalny-kanclerz kurii jest sekretarzem rady biskupiej i rejestruje jej kolegialną pracę ${ }^{59}$.

Nieporozumienia co do składu i funkcji rady biskupiej doprowadzały niekiedy do postawienia pod znakiem zapytania kwestii reprezentatywności tego gremium. Miało to miejsce tam, gdzie nie przestrzegano przepisów o składzie rady przewidzianym przez KPK i były powoływane do niej inne podmioty bądź ze względu na funkcje realizowane $\mathrm{w}$ diecezji, bądź dla posiadania określonych kompetencji. Trzeba jednak skonstatować, że rada biskupia, tak jak jest unormowana w KPK, nie jest organem przedstawicielskim ani kurii, ani prezbiterium diecezjalnego ${ }^{60}$. Jeśli akurat chce się mówić o reprezentatywności rady, to trzeba ją widzieć w relacji do biskupa diecezjalnego, ponieważ rada biskupia jest wyrazem konkretnej organizacji kościelnej (ustroju) przejawiającej się w tym, że każdy

56 Diócesis de Pamplona y Tudela, Estatuto de la Curia Diocesana, art. 7.

57 Zob. Estatuto de la Curia Diocesana de Astorga, art. $22 \S 1$ www.diocesisastorga.es, [dostęp: 26.05.2017 r.].

58 Zob. tamże, art. 22 § 3-4.

59 Zob. Estatutos de la Curia Diocesana de Asidonia-Jerez..., art. 13 §1-3.

60 Antonio Viana podkreśla, że rada biskupia nie jest organem przedstawicielskim urzędów diecezjalnych, nawet tych należących do kurii, ponieważ KPK określa, iż składa się ona wikariuszy generalnych i biskupich, zob. tenże, Comentario al can. 473, s. 1049. 
biskup diecezjalny ma obowiązek (wikariusz generalny) lub chce (wikariusz biskupi) podzielić się z innymi swoją władzą rządzenia ${ }^{61}$. Tak więc członkowie rady, sprawujący władzę wykonawczą w imieniu biskupa, reprezentują tych, którym biskup musiał lub chciał udzielić swojej potestatis executivae.

\section{Relacja pomiędzy radą biskupią a radą kapłańską i kurią diecezjalną}

To, co dotychczas powiedziano o radzie biskupiej, pozwala na postawienie pytania o stosunek rady biskupiej do rady kapłańskiej. Jak wiadomo, tylko radę kapłańską KPK nazywa senatus episkopi ${ }^{62}$, wskazując przez to jej pierwszeństwo względem wszystkich innych organizmów, które wspomagają biskupa. Pierantonio Pavanello słusznie twierdzi, że trzeba dokładnie określić konkretny (i specyficzny) zakres tego priorytetu. Rada kapłańska jest „senatem biskupa” ponieważ jest to miejsce, w którym jest reprezentowane całe prezbiterium i w postaci zinstytucjonalizowanej manifestuje wobec biskupa swój udział w zadaniu rządzenia na sposób doradztwa. Rada kapłańska funkcjonuje na etapie przygotowywania decyzji w zakresie zarządzania - funkcja rady biskupiej lokuje się w fazie urzeczywistnienia decyzji. Kanon 473 § 4 KPK nawiązując do funkcji koordynacyjnej rady biskupiej potwierdza tę wykładnię. Nie jest więc poprawne myślenie o radzie biskupiej jako o organizmie wąskim (ograniczonym), któremu powierzane byłyby kwestie delikatniejsze, gdy tymczasem radzie kapłańskiej pozostawiano by tylko najbardziej ogólne tematy. Podobnie nie wydaje się poprawnym twierdzenie, że rada biskupia jest miejscem wyznaczonym do rozpatrywania kwestii personalnych (na przykład, mianowania na urzędy kościelne). Różnica między tymi dwoma radami nie powinna być wyodrębniana $\mathrm{w}$ przedmiocie ich kompetencji, ale $\mathrm{w}$ różnym wkładzie, wnoszonym przez nie w wykonywanie władzy biskupiej ${ }^{63}$.

Nasuwa się jeszcze jedno pytanie: jaka jest relacja rady biskupiej do kurii diecezjalnej. Funkcje rady biskupiej nie mogą być ograniczane do koordynacji działalności kurii diecezjalnej. Kanon 473 § 4 KPK stwierdza,

\footnotetext{
61 Zob. P. Pavanello, Il consiglio episcopale (can. $473 \S 4$ )..., s. 75.

62 Zob. kan. $495 \S 1$ KPK.

63 Zob. P. Pavanello, Il consiglio episcopale (can. 473 § 4)..., s. 76.
} 
że kompetencje omawianej rady dotyczą zakresu znacznie szerszego, czyli promowania całej działalności duszpasterskiej diecezji. Z jednej strony wikariusz generalny i wikariusze biskupi są częścią kurii, z drugiej - nie mogą być oni postrzegani jako zwykli pracownicy zatrudnieni w kurii. Ich szczególna relacja $\mathrm{z}$ biskupem stawia ich $\mathrm{w}$ jakiś sposób ponad samą kurią - $\mathrm{z}$ tego powodu $\mathrm{w}$ radzie biskupiej wikariusze nie działają jako członkowie kurii, ale wykonują prawdziwą i własną współodpowiedzialność z biskupem, jako członkowie jego rady.

Dla rady biskupiej kuria odgrywa rolę instrumentalną taką, jaką ma względem biskupa diecezjalnego. $W$ tej perspektywie urzędy kurii będą mieć za zadanie dostarczyć radzie biskupiej elementy wiedzy odnośnie do poruszanych spraw, opracowując - gdy jest to wymagane - projekty i rezolucje, które biskup będzie omawiać ze swoimi wikariuszami i którym potem będzie powierzać ich wykonanie.

Nie można pojmować rady biskupiej jako organu koordynacji działalności wewnętrznej kurii. Do tego celu może być pożyteczny inny organ rada kurii, która skupia $\mathrm{w}$ sobie wikariusza generalnego oraz moderatora kurii, wikariuszy biskupich, którym powierzono zadania w jednej, określonej dziedzinie życia całej diecezji (nie tych z kompetencjami w określonej części diecezji lub w odniesieniu do pewnej grupy wiernych, ale np. dla formacji stałej duchowieństwa i życia konsekrowanego czy dla przepowiadania słowa Bożego i liturgii), kanclerza i kierowników różnych urzędów kurialnych. Rada kurii, różna od rady biskupiej, była przewidywana dla Wikariatu Rzymu w konstytucji apostolskiej Vicariae potestatis ${ }^{64}$.

Niektórzy prawodawcy partykularni chcąc być wierni przepisom kodeksowym o radzie biskupiej, ustanawiają radę kurii. Przykładowo Estatuto de la Curia Diocesana diecezji Pamplona i Tudela stwierdza:

By ułatwić dobre funkcjonowanie kurii, zostaje ustanowiona rada kurii pod przewodnictwem arcybiskupa, a tworzona przez wikariusza generalnego,

64 „Il Vicegerente e i vescovi ausiliari formano, sotto la guida del Cardinale vicario e insieme ad esso, il consiglio episcopale della diocesi", Paulus PP. VI, Constitutio apostolica „Vicariae potestatis" (6 gennaio 1977), art. 3 § 4, AAS 69(1977), s. 5-18. W nowej strukturze Wikariatu Rzymu przewidzianej przez konstytucję apostolską Ecclesia in urbe nie mówi się o radzie kurii, ale jedynie o radzie biskupiej formowanej przez wiceregensa (z godnością arcybiskupa), biskupów pomocniczych i prałata-sekretarza, pod przewodnictwem kardynała Wikariusza, zob. Ioannes Paulus PP. II, Constitutiones apostolicae "Ecclesia in Urbe". Vicariatus Urbis nova ratione ordinatur (1 ianuarii 1998), AAS 90(1998), s. 177-193; P. Pavanello, Il consiglio episcopale (can. $473 \S 4$ )..., s. 76-77. 
moderatora kurii, sekretarza-kanclerza i ekonoma. Rada ta zbiera się zwykle każdego tygodnia, a jej istotnym celem jest stała kontrola funkcjonowania kurii i koordynacja całej jej działalności ${ }^{65}$.

\section{Podsumowanie}

Instytucja „rady biskupiej” jest nowa w życiu Kościoła partykularnego, choć faktycznie istniała w niektórych kuriach biskupich, jeszcze przed podjęciem reformy kodeksu.

Rada biskupia jest podmiotem, który jest częścią organizacji niektórych Kościołów partykularnych, nieobowiązkowym do ustanawiania we wszystkich diecezjach. To gremium jest kształtowane przez wikariusza generalnego i wikariuszy biskupich, czyli tych kapłanów, którzy sprawują $\mathrm{w}$ formie zastępczej własną władzę wykonawczą biskupa diecezjalnego.

Celem rady biskupiej, złożonej z wikariuszy biskupa, jest koordynowanie całego duszpasterstwa diecezjalnego.

Z uwagi jednak na to, że KPK w sposób zdecydowany, niebudzący wątpliwości, przewiduje skład rady biskupiej, to gremium to nie będzie mogło być tworzone w tych diecezjach, w których biskup nie uzna za konieczne, aby mianować wikariuszy biskupich.

Consilium episcopale nie posiada swojej własnej władzy; jedyną władzą w niej wykonywaną jest władza biskupa diecezjalnego.

Rada biskupia nie pełni funkcji czysto doradczej - w przeciwieństwie do członków rady kapłańskiej - faktycznie, wikariusze nie mają tylko zadania doradzać biskupowi, ale oni także realizują jego decyzje, nie jako zwyczajni wykonawcy, ale jak tytulariusze prawdziwej władzy.

Gdy idzie o kompozycję rady biskupiej, to jest ona złożona wyłącznie z wikariuszy biskupa, w celu koordynowania całego diecezjalnego duszpasterstwa.

Rada kapłańska funkcjonuje na etapie przygotowywania decyzji w zakresie zarządzania, zaś funkcja rady biskupiej lokuje się w fazie urzeczywistnienia decyzji.

Dla rady biskupiej kuria odgrywa rolę instrumentalną - taką, jaką ma względem biskupa diecezjalnego.

${ }^{65}$ Diócesis de Pamplona y Tudela, Estatuto de la Curia Diocesana, art. 8. 
Rada biskupia nie jest organem koordynacji działalności wewnętrznej kurii. Do tego celu może być pożyteczny inny organ - rada kurii, która skupia w sobie wikariusza generalnego oraz moderatora kurii, wikariuszy biskupich, którym powierzono zadania w jednej, określonej dziedzinie życia całej diecezji (nie tych z kompetencjami w określonej części diecezji lub w odniesieniu do pewnej grupy wiernych, ale np. dla formacji stałej duchowieństwa i życia konsekrowanego czy dla przepowiadania słowa Bożego i liturgii), kanclerza i kierowników różnych urzędów kurialnych.

Słowa kluczowe: rada biskupia, biskup diecezjalny, wikariusz generalny, wikariusz biskupi, kuria diecezjalna

\section{Bibliografia}

\section{Źródła}

Arcidiocesi di Napoli, Statuto della Curia (14 settembre 2015), http:/ / www.chiesadinapoli.it [dostęp: 3.06.2017 r.].

Codex Iuris Canonici auctoritate Ioannis Pauli PP. II promulgatus. Kodeks Prawa Kanonicznego, przekład polski zatwierdzony przez Konferencje Episkopatu, Poznań 1984.

Codex Iuris Canonici, Schema novissimum iuxta placita Patrum Commissionis emendatum atque Summo Pontifici praesentatum, Typis Polyglottis Vaticanis 1982.

Congregaticio pro Episcopis, Direttorio per il ministero pastorale dei vescovi "Apostolorum successores" (22 febbraio 2004), Città del Vaticano 2004.

Diócesis de Pamplona y Tudela, Estatuto de la Curia Diocesana (1 noviembre 2003), http:/ / www. iglesianavarra.org [dostęp: 26.05.2017 r.].

Estatuto de la Curia Diocesana de Astorga, www.diocesisastorga.es [dostęp: 26.05.2017r.].

Estatuto de la Curia Diocesana de Ávila (3 abril 2002), Ávila 2002.

Estatuto de la Curia Diocesana de la Archidiócesis de Madrid (1 marzo 1999), http:// www.lavozdelcardenal.archimadrid.com [dostęp: 26.05.2017 r.].

Estatuto de la curia diocesana Diócesis de Albacete (8 diciembre 2003), http:/ / www. diocesisalbacete.org/documentos/transparencia [dostęp: 26.05 .2017 r.].

Estatutos de la Curia Diocesana de Asidonia-Jerez diócesis de Asidonia Jerez, „Boletín Oficial del Obispado de Asidonia-Jerez", época 2, separata nr 14, https:/ / www. diocesisdejerez.org/index.../separatas-2001-2008 [dostęp: 1.05. 2017 r.]. 
Ioannes Paulus PP. II, Adhortatio apostolica post-synodalis de Episcopo ministro evangelii Iesu Christi pro mundi spe "Pastores gregis" (16 octobris 2003), "Acta Apostolicae Sedis" 96(2004), s. 825-924; tekst w j. polskim: Jan Paweł II, Posynodalna adhortacja apostolska „Pastores gregis" Ojca Świętego Jana Pawta II. O biskupie studze Ewangelii Jezusa Chrystusa dla nadziei świata, "L'Osservatore Romano" [wyd. pol.] 25(2004), nr 1 (259), s. 4-48.

Ioannes Paulus PP. II, Constitutiones Apostolicae "Ecclesia in Urbe”. Vicariatus Urbis nova ratione ordinatur (1 ianuarii 1998), "Acta Apostolicae Sedis" 90(1998), s. 177-193.

Kongregacja do spraw Biskupów, Dyrektorium o pasterskiej postudze biskupów „Apostolorum successores", Kielce 2005.

Obispado de Palencia, Estatuto de la Curia Diocesana (1 septiembre de 2012), www. diocesispalencia.org [dostęp: 18.05.2017 r.].

Paulus PP. VI, Constitutio apostolica "Vicariae potestatis" (6 gennaio 1977), "Acta Apostolicae Sedis" 69(1977), s. 5-18.

Pontificia Commissio Codici Iuris Canonici Recognoscendo, Coetus studii «De sacra Hierarchia» (olim «De Clericis») (Sessio VI), "Communicationes" 24(1992), s. 32-55.

Pontificia Commissio Codici Iuris Canonici Recognoscendo, Opera Consultorum in parandis canonum schematibus, II. De Clericis-De Sacra Hierarchia, „Communicationes" 5(1973), s. 216-235.

Pontificia Commissio Codici Iuris Canonici Recognoscendo, Opera Consultorum in recognoscendis schematibus canonum. Coetus «De populo Dei», „Communicationes" 13(1981), s. 111-150.

Pontificia Commissio Codici Iuris Canonici Recognoscendo, Opera Consultorum in recognoscendis schematibus canonum. Coetus «De populo Dei», „Communicationes" 14(1982), s. 116-230.

Pontificia Commissio Codici Iuris Canonici Recognoscendo, Relatio complectens synthesim animadversionum ab Em.mis atque Exc.mis patribus Commissionis ad novissimum schema Codicis Iuris Canonici exhibitarum, cum responsionibus a secretaria et consultoribus datis, Città del Vaticano 1981.

Pontificia Commissio Codici Iuris Canonici Recognoscendo, Schema "De Populo Dei”, Typis Polyglottis Vaticanis 1977; tekst w j. polskim: Schemat „O Ludzie Bożym", [w:] E. Sztafrowski (red.), Posoborowe Prawodawstwo Kościelne, t. 10, z. 2, Warszawa 1979, s. 125-388.

Regulamin Kurii Diecezjalnej w Tarnowie (31 grudnia 2010), „Currenda” 161(2011), nr 1, s. 63-77.

Schema Codicis Iuris Canonici, Libreria Editrice Vaticana 1980.

Statuto della Curia Diocesana della diocesi di Albenga-Imperia, http:/ / repertoriogiuridico.chiesacattolica.it/statuto-della-curia-della-diocesi-di-albenga-imperia [dostęp: 3.06.2017 r.]. 


\section{Literatura}

Arrieta J.I., Órganos de participación y corresponsabilidad en la Iglesia diocesana, "Ius Canonicum" 34(1994), nr 68, s. 553-593.

Chiappetta L., Il Codice di Diritto Canonico. Commento giuridico-pastorale, Roma 1996.

Daneels F., De dioecesanis corresponsabilitatis organis, „Periodica de Re Morali Canonica Liturgica" 1985, t. 74, s. 301-324.

Giuliani G., I canoni generali sulla curia diocesana, „Apollinaris” 61(1988), nr 1/2, s. 109-153.

Krukowski J. (red.), Komentarz do Kodeksu Prawa Kanonicznego, t. 2, ks. 2, cz. 1. Lud Boży, Poznań 2005.

Marchetti G., La Curia come organo di partecipazione alla cura pastorale del vescovo diocesano, Roma 2000.

Marzoa A., J. Miras, R. Rodríguez-Ocaña (red.), Comentario exegético al Código de Derecho Canónico, t. 2, Pamplona $1996^{3}$.

Mendonca A., The Structural Components of the Diocesan Curia, "Canonical Studies” 16(2002), http:/ / www.canonlawsocietyindia.org [dostęp: 2.06.2017 r.].

Morgante M., La Chiesa particolare nel Codice di diritto canonico: commento giuridico-pastorale, Milano 1987.

Pavanello P., Il consiglio episcopale (can. 473 § 4). Commento a un canone, "Quaderni di Diritto Ecclesiale" 18(2005), nr 1, s. 70-78.

Perez Diaz A., Los vicarios generales y episcopales en el Derecho Canónico actual, Roma 1996.

Perlasca A., I vicari generali ed episcopali, „Quaderni di Diritto Ecclesiale” 18(2005), nr 1, s. 31-54.

Serres López de Guereñu R., La figura del vicario para la vida consagrada: aspectos canónicos, „Revista Espańola de Derecho Canónico” 62(2005), nr 159, s. 625649.

Viana A., Comentario al can. 473, [w:] A. Marzoa, J. Miras, R. Rodríguez-Ocaña (red.), Comentario exegético al Código de Derecho Canónico, t. 2, Pamplona 199633, s. 1046-1050.

\section{EPISCOPAL COUNCIL - THE COLLEGIAL CONSULTATION AUTHORITY OF THE DIOCESAN CURIA DEALING WITH MINISTERIAL ISSUES}

\section{Sum mary}

If the bishop decides that it is necessary to intensify ministerial activity, he can establish the episcopal council consisting of general vicars and bishop vicars. The article discusses the institution of the episcopal council. 
First it emphasizes the fact that the episcopal council is a new collegial consultation authority of the diocesan curia. Then it outlines the composition of the episcopal council. Finally it discusses the relationship between the episcopal council and the priestly council as well as the diocesan curia.

Key words: episcopal council, diocesan Bishop, Vicar general, episcopal Vicar, diocesan curia

\section{ЕПИСКОПСКИЙ СОВЕТ - КОЛЛЕГИАЛЬНО-КОНСУЛЬТАТИВНЫЙ ОРГАН ДИОЦЕЗНОЙ КУРИИ ПО ВОПРОСАМ ПАСТЫРСТВА}

\section{Резюме}

В тех случаях, когда епископ считает необходимым более целесообразно увеличить пастырскую деятельность, он может учредить епископский совет, состоящий из генеральных викариев и епископских викариев. В этой статье рассматривается вопрос об учреждении епископского совета.

Сначала было обращено внимание на тот факт, что епископский совет является новым консультативным органом при епископальной курии. Затем был представлен вопрос о составе епископского совета. В свою очередь, обсуждались отношения между епископским советом, пресвитерским советом и епархиальной курией.

Ключевые слова: епископский совет, епархиальный епископ, генеральный викарий, епископский викарий, епархиальная курия 